Contacts

Publisher: Ben Crowe

Editor: Paul Smaglik

Marketing Manager: David Bowen

European Head Office

London

The Macmillan Building

4 Crinan Street

London N1 9XW, UK

Tel +44 (0) 2078434961

Fax +44 (0) 2078434996

e-mail: naturejobs@nature.com

Naturejobs Sales Director

Nevin Bayoumi (4978)

UK/ RoW/ Ireland:

Matt Powell (4953)

Andy Douglas (4975)

Frank Phelan (4944)

Netherlands/ Italy/ Spain/

Portugal/ Belgium:

Evelina Rubio Hakansson (4973)

Scandinavia: Sille Opstrup (4994)

France/ Switzerland:

Amelie Pequignot (4974)

Natureevents:

Paul Constant (4954)

Production Manager: Billie Franklin

To send materials use London

address above.

Tel +44 (0) 2078434814

Fax +44 (0) 2078434996

e-mail: naturejobs@nature.com

Naturejobs web development:

Tom Hancock

Naturejobs online production

Ben Lund

European Satellite Office

Germany/ Austria:

Patrick Phelan, Odo Wulffen

Tel + $498954905711 /-2$

Fax + 498954905720

e-mail: p.phelan@nature.com

o.wulffen@nature.com

US Head Office, New York

345 Park Avenue South,

10th Floor, New York, NY 10010-1707

Tel +1 8009897718

$\mathrm{Fax}+18009897103$

e-mail:naturejobs@natureny.com

US Sales Manager: Peter Bless

US Advertising Coordinator

Linda Adam

Japan Head Office, Tokyo

MG Ichigaya Building (5F),

19-1 Haraikatamachi,

Shinjuku-ku,

Tokyo 162-0841

Tel +81 332678751

Fax +81332678746

Asia-Pacific Sales Director:

Rinoko Asami

e-mail: rasami@naturejpn.com

\title{
naturejobs
}

\section{A question of gender}

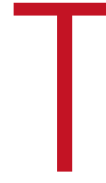

he statistics agree that women are disproportionately represented in science (see Nature 426, 8; 2003). But there is little agreement on how to redress the balance. Some plans call for legislation, others for quotas. Some advocates hope that female pioneers will lead the way, while others worry that high-profile successes will be accused of getting breaks because of their gender.

But the first step is to recognize a problem. The European Commission (EC) has taken that step and is trying to address it by asking grant applicants to provide gender-equality plans for their research teams in the current round of EC funding. Many scientists, however, are uncomfortable with the idea of legislating for gender equality (see page 210). Similarly, when European research centres have tried to target women for their ranks (see page 211), their projects attracted many qualified applicants — but also charges of reverse discrimination, inevitable in any quota system.

Even the pioneers disagree. Persis Drell became director of research at the Stanford Linear Accelerator Center in California last year, but says that she has reservations about being regarded as a role model for her gender. Biologist Shirley Tilghman, president of Princeton University, New Jersey, since 2001, takes the opposite approach, canvassing for more women in science.

As women scientists in Europe begin to rise to the top of their careers, they must grapple with similar issues. But at least that is starting to happen. Harriet Wallberg-Henriksson will become the first female president of Stockholm's Karolinska Institute next year.

Yet ultimately, it may be that market forces resolve the problem. If, as planned, Europe does increase its investment in research and development to $3 \%$ of gross domestic product by 2010 , there won't be enough male scientists to do the work.

\section{Paul Smaglik}

Naturejobs editor
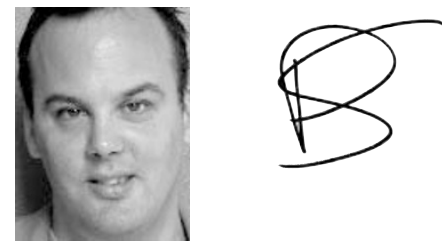

\section{Contents}

SPECIAL REPORT

Europe attempts to promote

women scientists

\section{WWW.NATUREJOBS.COM}

Career centre

Information on the scientific job market

FOCUS

SPOTLIGHT

RECRUITMENT

ANNOUNCEMENTS

EVENTS 